DOI: $10.30519 /$ ahtr.749680

Advances in Hospitality and Tourism Research (AHTR)

\title{
COULD HAPPINESS BE AN ASSESSMENT TOOL IN SUSTAINABLE TOURISM MANAGEMENT?
}

\author{
Selvet NIYAZIEVA ${ }^{1}$ \\ University of Economics - Varna, Bulgaria \\ ORCID: 0000-0002-2655-1850 \\ Vladimir ZHECHEV \\ Department of Marketing, University of Economics - Varna, Bulgaria \\ ORCID: 0000-0001-6677-9537
}

\begin{abstract}
The continuous commitment of companies from different sectors to demonstrate ethical demeanor of their business activities and bring about development of the respective economy, while maintaining the society's wellbeing, has seen enormous activism in the last years. This has been very much evident in the tourism sector where the responsibility towards the society takes many forms, ranging from initiatives to promote activities for cleaner environment to programs for supporting quality of life and fair payment for employees and their families. Given this shift in policy making and execution of tourism market players, this paper aims to critically evaluate the extant sources of literature in the field of sustainable management of tourism, happiness concept in sustainable development and tourism, and on this premise - to blueprint a conceptual model that can serve entities in the industry for effective running of their sustainability courses of action. Happiness was accepted as one of the important goals of Sustainable Development with some United Nations resolutions. In this relation, happiness became an up-to-date topic in the Sustainable Development agenda as a way for holistic measure of success on the national and international levels. So, the authors would like
\end{abstract}

Article History

Received 29 June 2020

Revised 17 September 2020

Accepted 23 September 2020

\section{Keywords}

Sustainable tourism

Tourism development

Sustainable tourism management

Happiness

Sustainable development goals

\footnotetext{
${ }^{1}$ Address correspondence to Selvet NIYAZIEVA, Department of Marketing, University of Economics

- Varna, BULGARIA. E-mail: selvet_niyazieva@ue-varna.bg
} 
to propose Business Gross Happiness as an indicator for companies in the sustainable tourism industry to measure their success in their course to sustainable development goals.

\section{INTRODUCTION}

In our days, the issues of sustainable development (SD) and sustainable tourism (ST) became a reality for 21st century`s society together with the big number of challenges, including the unprecedented economic growth of the 20-th century, poverty, exhaustion of natural resources, urbanization, climate change, the rapid population growth, innovations in technologies, etc. (Martin \& Schouten, 2012, p. 6-8). Scientists warned that if the economic growth continues at the same pace, the limited environmental resources will be exhausted within the next 100 years (Precup \& Hellendoorn, 2011). In this regard, the concept of SD arises as a result of the realization of the need for constructive ideas to overcome the negative phenomena in modern society (as carbon footprint, lack of regulation, overconsumption of some resources, pandemics, etc.). In this sense and the scope of authors' paper, $\mathrm{SD}$ appears to be a kind of opposition to the norms existing in society and the patterns of behavior in them. At the same time, it embodies new values and principles of regulation of economic, social, and environmental processes. During the 66-th Session of the United Nations (UN) General Assembly in 2012, the international conference "Defining a New Economic Paradigm: The Report of the High-Level Meeting on Wellbeing and Happiness" was held with the aim of incorporating the goal of societal happiness into the UN Sustainable Development Goals (SDGs) (Tideman, 2016). Happiness becomes an up-to-date issue in SD agenda after its acceptance as one of the important goals with UN resolution 65/309 (Happiness: towards a holistic approach to development (NDP Steering Committee and Secretariat, 2013) and resolution 66/281 which accepted March 20-th as International Day of Happiness (UN, n.d.; UN, 2012). The issues of new economic paradigm, based on the parity and indivisibility of the three pillars of SD - social, economic, and environmental wellbeing together defining gross global happiness, was broadly discussed (Roshina \& Artyukhova, 2016).

In the context of SD, the tourism industry could have multifaceted negative impacts including, but not limited to quality of life in highly visited tourist destinations (Gil-Saura \& Ruiz-Molina, 2019), local ecology (Sezerel \& Kaymaz, 2019), climate change (Panwar \& Singh Rautela, 2019) 
environmental hazards causing death of local residents (Jhamb, 2019) and disruption of coastal areas (Reineman \& Ardoin, 2018). These negative impacts could be seen as prerequisites for the emergence of the sustainable tourism concept. This concept has been advancing for over 30 years, becoming increasingly relevant in national and international agendas. In 1999 tourism was included as a strategic sector for SD from the UN commission for SD, but the key role played by sustainable tourism was not established until the Rio+10 and Rio+20 Earth Summit (Aall, 2014). Today there is no doubt about the importance of Sustainable Tourism, especially since the UN declared 2017 year for International year of Sustainable Tourism for development, thus highlighting the potential of tourism to contribute to sustainability and help achieve the goals of the 2030 Agenda. The UN general assembly has adopted several resolutions acknowledging its importance as a tool for development and environmental protection (UNWTO, 2017). In light of this, sustainable tourism development (STD) is a widely argued topic in academic literature. Given its complex nature, tourism continues to play a significant role in the presence of everincreasing challenges related to the environment and society (Kaushal \& Sharma, 2016). The debate for employing sustainable practices in tourism emerges as most stakeholders in the field deem this can enhance the reputation both of tourism entities/destinations and the stakeholder groups. At the same time, much doubt is casted over the potential economic efficiency of STD. Although many sources of existing literature in the field have delved into drafting proposals, singling out strategies, outlining impacts, etc., a major body of academic work revolves increasingly around the application of working models into practice (in specific regions of the world). The scope of this paper covers review of existing literature in the field of STD, happiness in the context of SD and tourism, and based on this analysis, the authors want to propose a model of an assessment framework for companies' in the tourism sector adopting sustainable tourism management.

\section{THE NEXUS BETWEEN SD, ST AND HAPPINESS: PREMISES FOR CHANGE OF THE CURRENT (NOT SO SUSTAINABLE) MODEL OF TOURISM MANAGEMENT}

"Sustainable development" is viewed as a complex concept that consolidates traditional perceptions of the relationship between humanity and nature, giving them a new meaning consistent with modern social theory and practice. The authors' analysis of the theoretical studies shows 
that more than 50 definitions are given for the concept of sustainable development. Most of them are in the context of global and regional sustainable development or cover only individual aspects like economic or social. The modern meaning of the term "sustainability" is used for the first time in 1972 in the documents of the Stockholm conference on environmental issues and the first official definition of "sustainable development" is set out in the Brundtland Report where it is defined as "development that enables us to meet the needs of today's generation without compromising the ability of future generations to meet their needs" (Keeble, 1988, p. 45). Further, the concept was developed with the introduction of the definition of the "three pillars (Triple bottom line-3BL or people, profit, planet-3Ps)", which refers to the harmonious interaction between economic prosperity, social justice and the preserved environment (see Figure 1).

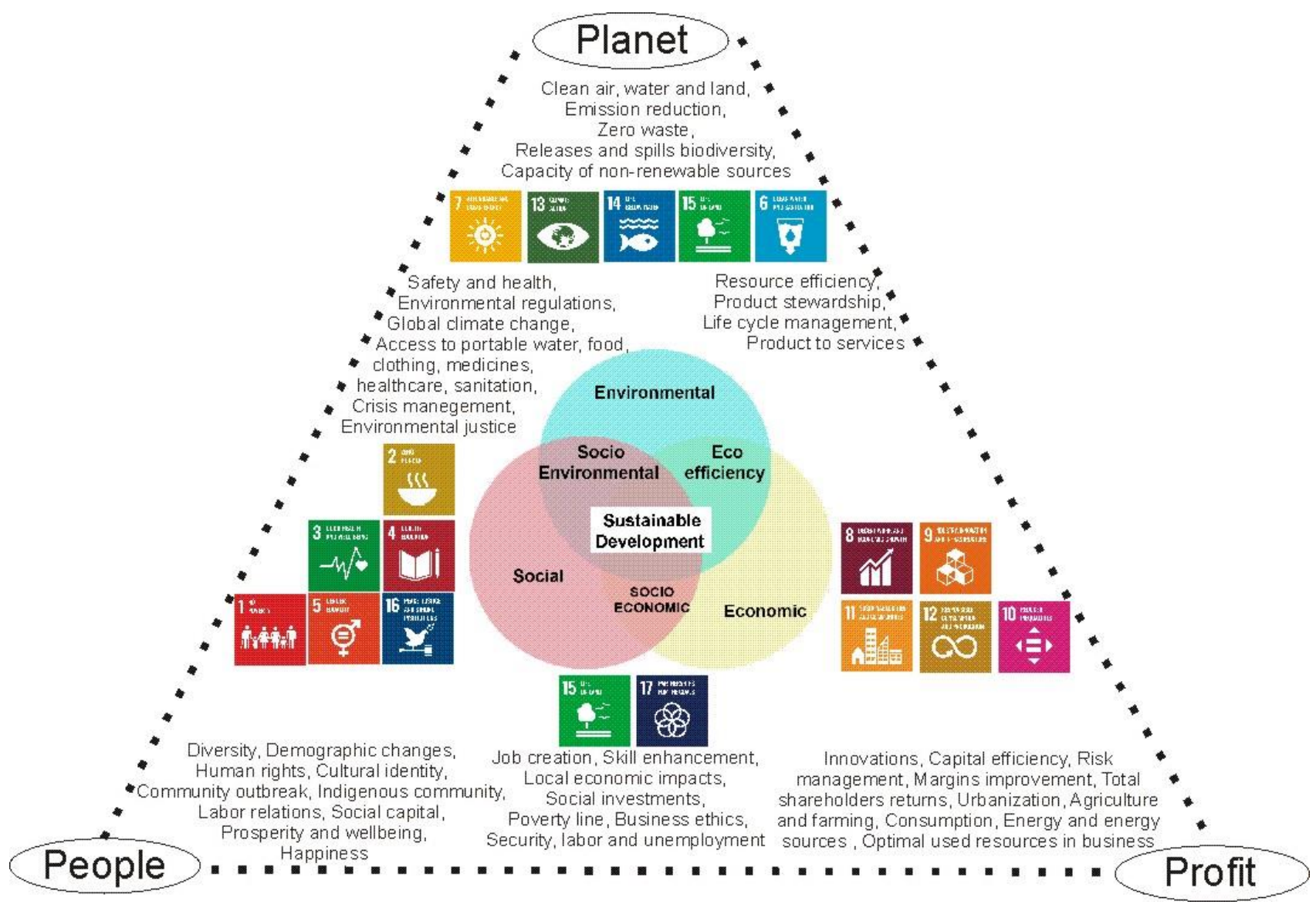

Figure 1. Graphic representation and interpretation of sustainability (economic, social, and environmental), sustainable development and distribution of SDGs. (Source: Authors) 
Figure 1 attempts to visualize the 3 main pillars of SD and the relationships between each of them with SDGs. Modern theories of SD assume that there are three dimensions of the concept: ecological, social and economic (Adams, 2006). In this paper, the researchers review happiness in its SD aspect (Figure 1 places happiness in the social sustainability pillar). In the authors' view, social sustainability could be defined as the longstanding ability of societies to secure the well-being of their members and in particular, their happiness and prosperity.

In recent years some concerns have been aroused about the fact that the Gross Domestic Product (GDP) do not provide a sufficiently detailed picture of social progress, which is related to improving the well-being of people and households. In this regard, the researchers see that in the scientific papers from last 12 years, alternative concept of measuring the quality of life and social progress in a society is becoming increasingly popular, which defines GDP as an insufficiently objective indicator (Copley, 2011; Stiglitz, 2019; Stiglitz et al., 2009). After series of UN Resolutions and visible changes in the consumers' behavior, it is necessary to understand that the notion of progress goes well beyond the income or consumption (Lukina et al., 2020) and that now it is a time for researchers to include other non-monetary aspects, such as weak social connections, psychological costs of alienation, etc., to see the whole picture. They marked that there is a need for a new and transformational approach for defining and measuring wellbeing. This need is felt with articulating of SDGs, which resonate deeply with "development with values" (Verma, 2017; Zhong, 2015). Unfortunately, the SDGs have a lack of coherence with wellbeing, leaving out culture, relationships, and even the work-life balance. These are the signals for change and emergence of alternative approaches. The change could begin with a change, from the pursuit of profit to the pursuit of wellbeing in all its levels (including happiness). In this regard, Gross National Happiness (GNH) is broadly accepted as measure of success instead of already mentioned GDP. From the GNH standpoint business is a central and vital pillar of the society that shares equal responsibilities from improving people's lives and contributing to their wellbeing and happiness. Businesses have to explore fostering happiness and wellbeing as an alternative business purpose (Niyazieva, 2020). Such focus requires a paradigm shift in managers thinking about the purpose of business (including personal and societal success).

Throughout the last few years, researches in the tourism industry have witnessed increased recognition of the intersection points between happiness and SD (Croes et al., 2017; Rivera et al., 2016). The extant 
literature in the field of tourism and those concerning the happiness of different stakeholders, in particular, is seeing increasing interest. There is plenty of evidence that happy people are healthier, more productive and creative (Fisher, 2010; Nokelainen, 2015; Sulakhe \& Bakre, 2019). Also, happiness is strongly linked to a destination's sustainability in terms of integrating economic, social and environmental objectives (Bimonte \& Faralla, 2016; Pratt et al., 2016; Rivera et al., 2016). The pursuit of a corporate objective (economic) to the detriment of another objective (social) may negatively affect human well-being, and may even endanger its survival. So, a holistic tourism management approach is needed. The shift from a commitment to action could only be achieved if SD moves from the periphery to the core of decision making in both public and private domains in tourism. It has significant potential to drive socio-economic development, environmental conservation and is mentioned in 3 of the 17th SDGs (relating to sustainable economic growth and decent employment, sustainable production and consumption and the conservation and sustainable use of oceans). Indeed, SDGs embody a worldwide commitment towards SD trough more holistic and integrated approaches and the SDGs on a Universal 2030 Agenda, are becoming more and more relevant in the tourism context. All these facts address for changes towards a more sustainable model of tourism management.

More specifically, the dynamic evolution of the tourism industry generates economic growth and creates employment opportunities (Hatipoglu et al., 2016) but at the same time, this growth causes tourists to consume more and more of finite resources, disposable products during their vacations and thus cause significant pollution and environmental problems. Moreover, the raw materials that are obtained for the creation of tourism products or services and the disposal of used products have also harmed the natural environment (He et al., 2018; Wu et al., 2019). Sustainable management of tourism with different sustainable activities could be an option to prevent these problems. Shift to sustainable tourism activities primarily cover the environmental, economic, social, and cultural aspects of development, which are the main pillars of the Gross National Happiness concept (GNH). The relations and connections between ST, GNH, SD and sustainability aspects for tourism can be observed in Figure 2. Since natural resources may be intensively exploited in the tourism business, tourism activities would sometimes pose major impacts on the environment, ecosystems, economy, society and culture. 


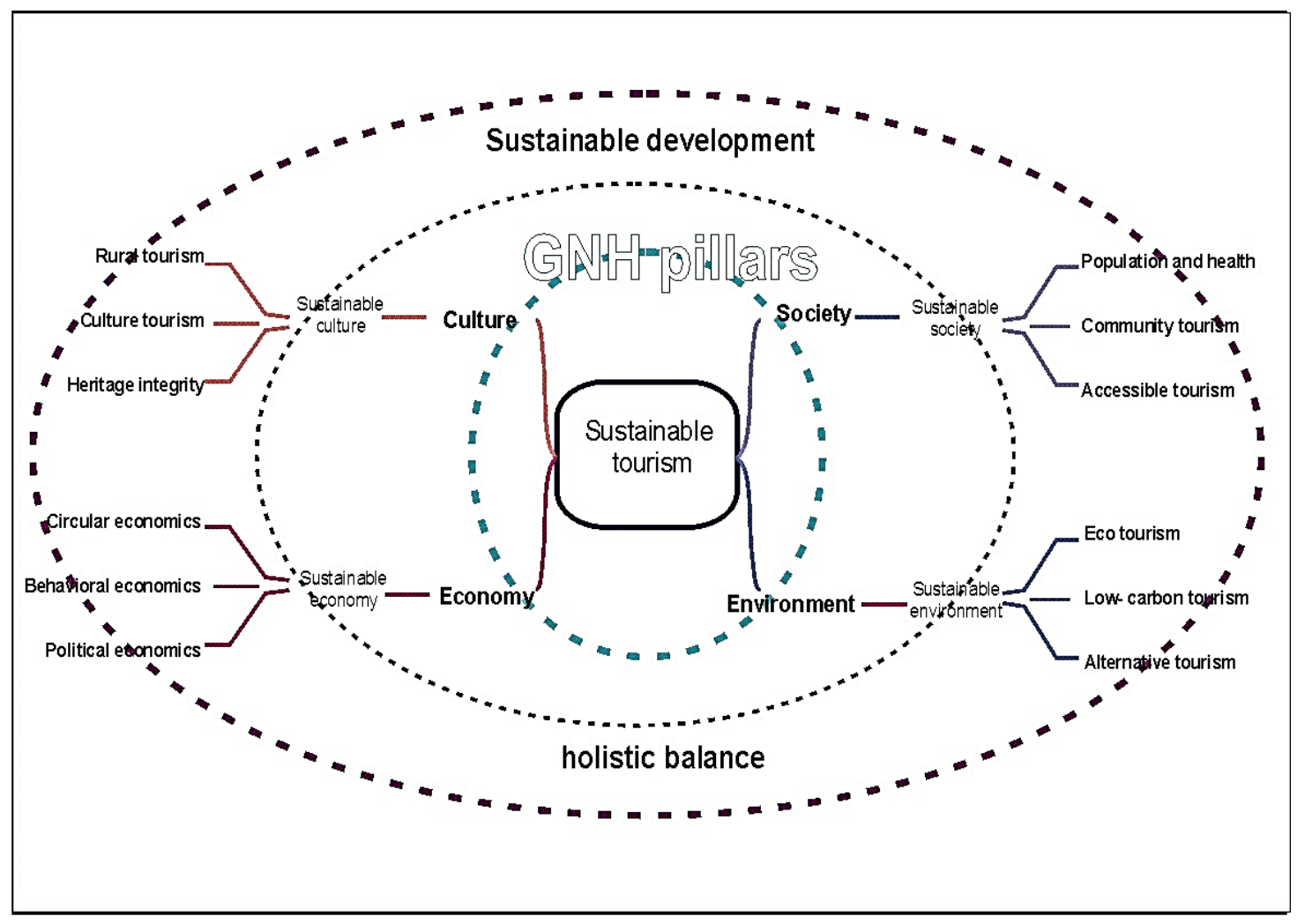

Figure 2. Connection and relation between ST, SD and GNH pillars (Source: Adapted and amended from Pan et al., 2018)

The rise of the sector requires special attention, new methods for management and tools for assessment are urgently needed in the industry to meet the requirements of 21-st century and the challenges of sustainable tourism (Firoiu et al., 2019; Zolfani et al., 2015). Therefore, a holistic balance among these main four pillars should be considered to guarantee the short and long-term development of sustainability for the tourism sector. Recent studies not only provide strategies to reduce negative environmental impacts but also generate working opportunities to increase social expectations and awareness. In this regard, and due to increasing interest in SD, and issues connected with it, the authors attempt to propose a framework for Sustainable Tourism Management (STM) through adopting the concept of Gross National Happiness. Today aspects of happiness become so important that some countries such as Bhutan, have a tourism policy fully guided by the doctrine of GNH, which gains increasing importance over other policies, thus enabling the country to gain a special reputation on the tourism map. The importance of these policies lies in the fact that there have been significant investments in socio-ecological development, conservation, promotion of culture and good governance. The happiness of the country's population is very important because they 
could transmit that feeling to the people who visit that country (AurelianoSilva et al., 2017; Coffey et al., 2015). Some studies describe the transformation of the tourism industry and for the organizations aiming at the satisfaction of employees is important to go beyond serving to be able to anticipate the situations and thus meeting the needs of the visitors.

The development of GNH witnesses a time that the world is in front of the threat of ecological collapse due to climate change, ecosystem loss and rapidly depleting natural resources, while concerns about persistent social issues such as poverty, inequality, exclusion, corruption, human rights abuses and pandemics are rising. In this context, since the introduction of the concept of SD, there are attempts to capture the performance of nations and companies in new frames, models, and indicators, starting with concepts such as the UN Development Index, the Triple Bottom Line, Corporate Social Responsibilities (CSR), etc. (Elkington, 1997; Epstein \& Buhovac, 2014). These frameworks in common go beyond measuring economic performance in confined financial terms, but instead advocate assessing a broader concept of value, generally comprising of the social, ecological, and economic dimension (Helliwell et al., 2018). On a global scale, this trend is expressed in objectives such as UN SDGs (See Fig.1). Alternatively, the triple value concept corresponds largely to the concept of GNH. The GNH pillars of socio-economic development, environmental conservation, and cultural preservation could be covered by definitions of economic, environmental, and societal value, respectively. GNH is based on the recognition that all stakeholders that make up the economy, society, and eco-system (the first three pillars of GNH) have specific needs that could be met. It is in the serving and balancing of those needs that sustainable value is generated.

Significant attention has been given to happiness at national level with the release of 1-st World happiness report (Helliwell et al., 2018). After that, GNH has been operationalized at governmental level but not at the business level (even in Bhutan, the birthplace of the concept). The idea for incorporating GNH values into business was first proposed by Dasho Tobgay, at the 6-th International Conference on GNH (Zangmo et al., 2017). He described the current business model of overemphasizing profit maximization and increasing shareholder value at the cost of environment and community as unsustainable. Many businesses today rely only on financial indicators to measure their performance. But the authors should note that the financial reports fail to clarify the degree to which businesses impact the environment and communities. For example, tourism, a business, which often pollutes and destroys habitats, (by building of more 
hotels in the coastal areas to accommodate an increasing number of tourists, often increase the sewage runoff and sedimentation (Habibullah et al., 2016), another example- an average golf resort, uses as much water as 60,000 rural villagers and at the same time also uses 1500 kilos of chemical fertilizers, pesticides, and herbicides per year, etc. (The World Counts, 2019), is seen to rank at the top due to the mere presentation of financial statements with higher returns, but it rarely reveals its repercussions on local residents and the environment. This example demonstrates the need for recognizing and managing these costs and risks and could be accepted as a prerequisite for integrating GNH values into business organizations. Essentially, the model that we propose intends to measure the success of a business in the sector by its ability to serve, facilitate, and engage with its stakeholders in line with the GNH, SDGs and STM concept. This requires rethinking business indicators used for measuring the success or the failure in the sustainable tourism sector. Businesses have to realize that prosperity at the expense of the environment and community is not sustainable. Integrating GNH would essentially require businesses to value societal wellbeing over profit and concentrate on responsible behavior. This would coherently represent the core values of GNH.

As the authors already discussed, the gaps, premises and the negative impacts of tourism have led to a movement for reinstating the idea of social responsibility in business. Social responsibility redirected the business towards a stakeholder theory that suggests that the purpose of business should be to consider all who have an interest in or are affected by an organization's activity. The theory resonates with the values of GNH as integrating it requires businesses to sustain the competing interests of stakeholders. In the context of SD, happiness is broadly accepted as a measure of success and countries' prosperity. On a global level happiness is related to social sustainability (see Fig.1), on a business level social sustainability is represented by Corporate Social Responsibility (CSR) of the company. With the changes in the global policies and broad acceptance of SDGs and the program of UN in last years, we have seen a transition from classic indicators of success as Gross National Product/GDP to more holistic measures that include all three main aspects of sustainability - economic, social and environmental aspects. 


\section{CONCEPTUAL FRAMEWORK OF SUSTAINABLE TOURISM DEVELOPMENT}

Sustainability in policy making of various entities in the field of tourism has been tackled hard by the respective management teams. At the same time, the tendency of having ethical norms and values available on the corporate webpage has been fading out since customers are no longer looking at promises but are rather concerned about results. So instead of resting on past laurels, tourism has started to be geared against the long-lasting impact on the society, its employees, and more particularly - the customer wellbeing.

Multiple benefits could be traced down to the application of SD practices (Crabtree \& Gasper, 2020; Sharpley, 2020; Tien et al., 2020) in:

- Better relationships with employees,

- Retention of employees,

- Good media reputation,

- Differential advantage,

- Cost efficiency,

- $\quad$ Easy entry into new businesses, among others.

Taking a broader perspective of sustainability, the researchers see some up-to-date tendencies that are likely to steer the development of businesses in the near future. On the one hand, companies are very sensitive to investments in sustainability because of concerns with such initiatives' ability to pay off (Santos, 2020; Sweeney, 2020). On the other hand, despite the fact that customers are regularly encouraged to consume more, a growing number of them are inclined to make more ethical choices and diminish their environmental influence (Kraleva \& Ivanov, 2018; Zhechev, \& Zhecheva, 2019). At the same time, the feeling of individuals being incapable of generating a sensible change to the environment limits their empowerment to engage in sustainable actions. According to The Guardian (Baker, 2015), customers are requiring transparency as they take an increasing interest in the ethical practices of businesses.

More closely examined, tourism has received significant amount of attention from scholars striving to explore the precedents, impacts, key actors, performance indicators, climate effects, among other factors originating from engaging actively in sustainable tourism development. In particular, sustainable tourism has witnessed a considerable shift towards empirically tested papers, as opposed to conceptual papers (Ruhanen et al., 2015). Another interesting finding is claimed by Buckley (2012) who 
concludes that sustainable tourism is marked by four major fields: (1) responsible tourism, (2) ecotourism, (3) community tourism, and (4) conservation tourism. Despite the range of approaches to the study of sustainable tourism in different contextual settings, the field requires special attention to subfields given the geographical, ecological, political and customer-centric specificities involved.

While some authors focus their attention exclusively on the economic importance of sustainable tourism, others delineate sustainability in the context of the support provided by different stakeholders. This is evident in Table 1, which presents a synopsis of some studies in the area by looking at: (1) the aspect(s) of sustainable tourism studied, (2) country of study, and (3) critical considerations pertaining to every individual paper included.

Table 1. Review of existing literature in the field of sustainable tourism

\begin{tabular}{|c|c|c|c|}
\hline Source(s) & $\begin{array}{c}\text { Aspects of sustainable tourism } \\
\text { studied } \\
\end{array}$ & $\begin{array}{c}\text { Country of } \\
\text { study }\end{array}$ & Critical considerations \\
\hline $\begin{array}{l}\text { Moscardo G. } \\
(2008)\end{array}$ & $\begin{array}{l}\text { Discusses possible synergies between } \\
\text { tourism and economic activities that } \\
\text { can create premises for sustainability }\end{array}$ & & $\begin{array}{l}\text { Build upon the assumption that tourism } \\
\text { cannot be considered sustainable by } \\
\text { definition }\end{array}$ \\
\hline Sims, R. (2009) & $\begin{array}{l}\text { The influence of local food on } \\
\text { sustainable tourism experience }\end{array}$ & UK & $\begin{array}{l}\text { Focuses on the visitor's desire for } \\
\text { authenticity within the holiday experience } \\
\text { but disregards other elements that can alter } \\
\text { the customer experience }\end{array}$ \\
\hline $\begin{array}{l}\text { Choi, H. C., \& Murray, } \\
\text { I., (2010) }\end{array}$ & $\begin{array}{l}\text { Long-term planning, full community } \\
\text { participation and environmental } \\
\text { sustainability within tourism, are } \\
\text { critically related to support for } \\
\text { tourism, and to the positive and } \\
\text { negative impacts of tourism }\end{array}$ & US & $\begin{array}{l}\text { Suggested implications for local } \\
\text { governments for policy making in tourism }\end{array}$ \\
\hline $\begin{array}{l}\text { Erkuş-Öztürk, H., \& } \\
\text { Eraydın, A. (2010) }\end{array}$ & $\begin{array}{l}\text { The importance of governance } \\
\text { networks in sustainable tourism } \\
\text { development, the importance of } \\
\text { different scales of collaborative } \\
\text { governance networks, and the role of } \\
\text { organization building for } \\
\text { environmentally sustainable tourism }\end{array}$ & Turkey & $\begin{array}{l}\text { Accentuates on networking governance } \\
\text { practices for sustainable tourism } \\
\text { development }\end{array}$ \\
\hline Scott, D. (2011) & $\begin{array}{l}\text { Addressing climate change is } \\
\text { considered a prerequisite to } \\
\text { sustainable development }\end{array}$ & & Focuses on climate change mainly \\
\hline $\begin{array}{l}\text { Weaver, D. B. } \\
(2012)\end{array}$ & $\begin{array}{l}\text { Discusses incremental, organic, and } \\
\text { induced paths as an evolutionary } \\
\text { trajectory of destinations in their } \\
\text { pursue of sustainability (which is } \\
\text { viewed as a societal norm) }\end{array}$ & & $\begin{array}{l}\text { Emphasizes on sustainable mass tourism of } \\
\text { destinations and converge towards } \\
\text { environmental expediency }\end{array}$ \\
\hline Lee, T. H. (2013) & $\begin{array}{l}\text { Sustainable tourism indicators used: } \\
\text { community attachment, community } \\
\text { involvement, perceived benefits, } \\
\text { perceived costs, and support for } \\
\text { sustainable tourism development }\end{array}$ & Taiwan & $\begin{array}{l}\text { The support of community residents for } \\
\text { sustainable tourism is only considered from } \\
\text { the viewpoint of residents in southwest } \\
\text { Taiwan }\end{array}$ \\
\hline
\end{tabular}




\begin{tabular}{|c|c|c|c|}
\hline $\begin{array}{l}\text { Juvan, E., \& Dolnicar, S. } \\
\text { (2014) }\end{array}$ & $\begin{array}{l}\text { Reviews the attitude-behavior gap } \\
\text { between environmental } \\
\text { consciousness at home and during } \\
\text { holidays }\end{array}$ & & $\begin{array}{l}\text { It studies an important aspect of cognition } \\
\text { related to sustainability commitment. The } \\
\text { motivation of tourist to reduce their } \\
\text { negative impact limits the scope of the } \\
\text { study both geographically and } \\
\text { behaviorally }\end{array}$ \\
\hline $\begin{array}{l}\text { Pulido- Fernández, J. } \\
\text { I., Andrades- Caldito, } \\
\text { L., \& Sánchez- Rivero, } \\
\text { M. (2015) }\end{array}$ & $\begin{array}{l}\text { The study demonstrates that tourism } \\
\text { sustainability does not exert } \\
\text { influence on countries' major tourism } \\
\text { indicators in the short run, and does } \\
\text { not hamper profitability and } \\
\text { competitiveness. The findings are } \\
\text { diametrically opposed to the } \\
\text { assumption by many practitioners } \\
\text { that sustainability in tourism can } \\
\text { impede profitability. }\end{array}$ & $\begin{array}{l}\text { International } \\
\text { (82 countries) }\end{array}$ & $\begin{array}{l}\text { The paper relies on already available data } \\
\text { from the World Economic Forum and the } \\
\text { World Travel \& Tourism Council. }\end{array}$ \\
\hline $\begin{array}{l}\text { Hatipoglu, B., Alvarez, } \\
\text { M. D., \& Ertuna, B. } \\
\text { (2016) }\end{array}$ & $\begin{array}{l}\text { Analyzes barriers to the involvement } \\
\text { of stakeholders in the process of } \\
\text { planning for the development of } \\
\text { sustainable tourism. Highlights } \\
\text { financial interests and short-sighted } \\
\text { orientation as prevailing over } \\
\text { sustainable tourism initiatives. }\end{array}$ & Turkey & $\begin{array}{l}\text { Uses } 3 \text { dimensions of stakeholder } \\
\text { involvement in the planning of sustainable } \\
\text { tourism development: awareness, } \\
\text { knowledge, and vision. Local community } \\
\text { planning is opposed to stakeholders' } \\
\text { intentions. }\end{array}$ \\
\hline $\begin{array}{l}\text { Boley, B. B., McGehee, } \\
\text { N. G., \& Hammett, A. } \\
\text { T. (2017) }\end{array}$ & $\begin{array}{l}\text { Applies IPA } \text { (importance- } \\
\text { performance analysis) to study } \\
\text { resident } \quad \text { attitudes towards } \\
\text { sustainable tourism initiatives. }\end{array}$ & USA & $\begin{array}{l}\text { The study has interdisciplinary character as } \\
\text { it situates IPA with expectancy } \\
\text { confirmation theory. Performance } \\
\text { evaluations are measured against } \\
\text { sustainable tourism being an integral part } \\
\text { of the planning of the studied area units. }\end{array}$ \\
\hline $\begin{array}{l}\text { Hardy, A., \& Pearson, } \\
\text { L. J. (2018) }\end{array}$ & $\begin{array}{l}\text { Researches stakeholders' attitudes } \\
\text { and underlines the misalignment } \\
\text { between individual stakeholders and } \\
\text { stakeholder groups in the process of } \\
\text { development of sustainable tourism. }\end{array}$ & Australia & $\begin{array}{l}\text { Group specificity of stakeholders and } \\
\text { individual attitudes represents an } \\
\text { interesting area of study. The paper only } \\
\text { focuses on attitudes and propositions for } \\
\text { involvement which does not guarantee } \\
\text { sustainability performance. }\end{array}$ \\
\hline $\begin{array}{l}\text { Oliveira, E. } \\
(2018)\end{array}$ & $\begin{array}{l}\text { The article investigates the main } \\
\text { perceptions of residents as of the role } \\
\text { of entrepreneurs for the development } \\
\text { of sustainable tourism }\end{array}$ & Portugal & $\begin{array}{l}\text { The involvement of residents can reinforce } \\
\text { the development of sustainable tourism. } \\
\text { The paper drafts on residents' perceptions } \\
\text { mainly to sketch possible development } \\
\text { strategies. }\end{array}$ \\
\hline Kisi, N. (2019) & $\begin{array}{l}\text { The aim of this article is to present a } \\
\text { strategic approach that can help to } \\
\text { develop sustainable tourism at } \\
\text { touristic destinations and author was } \\
\text { chosen a province of Zonguldak, } \\
\text { Turkey, as research area. }\end{array}$ & Turkey & $\begin{array}{l}\text { The paper ventures into strategy building } \\
\text { for a specific region in Turkey. It elaborates } \\
\text { on product diversification from a cultural } \\
\text { point of view, reduction of environmental } \\
\text { impacts, implementation of sustainable } \\
\text { practices by local authorities (among } \\
\text { others). Mitigating the negative impact of } \\
\text { the tourism industry on social life, nature, } \\
\text { and culture is put into critical discussion. }\end{array}$ \\
\hline
\end{tabular}

Table 1 presents some of the highly cited papers related to sustainable tourism development (STD) spanning over a period of 20082019. The authors do not purport for the inclusion of the full spectrum of academic papers building upon sustainability in tourism. Instead, the table attempts to illustrate some of the aims and orientations of the extant 
literature in the field alongside with critical considerations from the viewpoint of the authors of this paper.

In particular, it can be observed that multiple papers compartmentalize the causes for the initiation of sustainable tourism development and pay significant attention to community involvement. Another cluster of authors accentuates on policy-making and networking as determinants of steering positive change in view of sustainability. Yet another group of authors underlines the economic importance of sustainable tourism. Last, but not least a body of literature is also devoted to the perceptions and attitudes of various stakeholders and on this premise - several strategic alternatives are proposed that are geared towards sustainable tourism performance. In this regard, in the text below, the researchers try to propose a new model of an assessment tool for companies in the tourism sector and their management.

\section{BUSINESS GROSS HAPPINESS (BGH): AN ASSESSMENT TOOL FOR THE MANAGEMENT OF COMPANIES PRACTICING STM}

A framework could be developed through adopting sustainable indicators for different companies, territories, or destinations depending on company characteristics. It would be able to give information on diverse implications of business operations and meanwhile could be used as a decision-making tool from business organizations in sustainable tourism to enhance desirable impacts on society and to mitigate adverse impacts. In the context of STM, the aim of the BGH framework could be an assessment of the overall functioning of the business organization, as per the GNH framework proposed by former prime minister of Bhutan Togbay (Dendup et al., 2018), and help the management to identify areas (domains and indicators) that require improvement in the company.

If business organizations in the tourism sector decided to make this move towards GNH, it will require from them a mindset shift and the company have to incorporate a non-economic indicators encompassing aspects such as job satisfaction, contribution to the community, and environmental considerations (Cloutier \& Pfeiffer, 2015; Hadi et al., 2018; Olesen \& Wiking, 2017), in addition to economic indicators. The businesses in the tourism sector have the opportunity to include GNH principles as one of their primary goals, so it could contribute to creating sustainable socio-economic conditions. Integrating these principles could allow companies to use a holistic approach for running their business and 
managers will assure that their business is running at full potential. Thereby, increasing employee's happiness and improving organizational conditions for happiness could support management to make an easy and smooth shift towards STM. Nowadays, consumers are more informed than ever and now they are looking for more than a product or quality of services when choosing a tourism destination. Supportive facts for these statements are the results of a research conducted in Spain that shows that consumers willing to pay more to visit a more sustainable tourism destination (PulidoFernández \& López-Sánchez, 2016). Another parallel research shows that $81 \%$ of global consumers seek responsibly produced products whenever possible (Chophel \& Ura, 2018; Nielson, 2018). Based on the recent studies mentioned above, the authors can summarize that consumers expect from them not only to make a profit, but they also expect companies to operate responsibly, addressing different social and environmental issues. Last but not least, the BGH could be considered as a branding process and it could help businesses to become profitable in the long run, if it gets established on core values.

What could be the advantages for companies in the sector, if they adopt GNH principles in business organizations and happiness as one of their end goals was discussed in previous sections of this paper. The authors also touched on the two central frameworks in the context of sustainable development: Corporate Social Responsibility (CSR) and Triple Bottom Line. CSR was discussed as an assessment tool and the authors have attempted to link it to SD. Now, the researchers will take a closer look at CSR as a framework for companies in the tourism industry. However, it should be noticed that some authors considered it as an inadequate, and perhaps detrimental, representation of 'organizational sustainability' (Malindretos, 2013). In this regard, CSR and 3BL are too specific, but they do not consider happiness as one of the business's end goals (Zangmo et al., 2017).

The increasing numbers of academic studies on happiness over the last 12 years, could be considered and perceived as one of the most important stimulating innovations in the economy. These studies provide experts with tools to test the "old hypotheses" in a new way and allow them to combine subjective researches with objective data (such as life expectancy, income and education) that allow them to be processed with logical models. In recent years, the recognition of happiness and prosperity as a global goals of the UN has been initiated by Bhutan, which used happiness $(\mathrm{GNH})$ as a measure of its national well-being instead of GDP (United Nations, 2012; Verma, 2017) since 1972. 
Referring to the resilient features of ST, SD and the shortcomings of existing instruments, the authors propose the BGH framework as a tool that could adopt the basic GNH principles and could be used to measure the happiness of companies in the tourism industry. In the last 8 years sustainable tourism researchers' and practitioners' attention has been dedicated to the relationship between tourism and subjective well-being, however, studies have mainly focused on the tourist side (Chen, 2016; Liu, 2013; Lohmann \& De Bloom, 2015; McCabe \& Johnson, 2013; Ram et al., 2013; Ramgulam et al., 2013; Schroeder, 2015). Few studies were focused on residents happiness (Bimonte \& Faralla, 2016; Croes et al., 2017; Rivera et al., 2016; Séraphin et al., 2018) and only 3 studies adopted some indicators of the GNH index in their researches (Chen, 2016; Croes, et al., 2017; Pratt, et al., 2016). According to the above mentioned, the authors can recap that happiness and GNH are not new to the tourism industry. There are enough empirical studies that show the correlation between happiness and tourism. Even though happiness is of paramount importance for the tourism industry, existing academic papers in the field do not review it from companies' viewpoints. The authors of this paper try to underline the importance of the tourism organizations' adoption and application of the GNH principles and behaviors in their relations with all stakeholders (Rosengren, 2018). In this regard, the Business Gross Happiness framework could be used as a tool to bring rational and responsible behavior in the tourism sector.

\section{STRUCTURE OF BGH FRAMEWORK}

BGH framework is constructed maintaining as base the GNH Index with its 9 domains and 33 indicators (Ura et al., 2012). It is developed by utilizing and adopting the 9-domain based framework, and these main domains are grouped under 2 main sub-groups of assessment components: Employees' happiness that contains 29 indicators with 115 variables, and Organizational condition for happiness that contains 21 indicators with 108 variables. Employees' happiness construct is dependent on collection of primary data via structured interviews. The second construct Organization condition for happiness is dependent on both: primary and secondary data. The primary data for it could be collected via structured interviews and the secondary data could be collected via official published company documents and reports. The researchers would like to clarify that the whole methodology utilized and adopted for this assessment tool is like this that is used for the GNH Index (Ura et al., 2012). This methodology has 3 steps: 
identifying and applying sufficiency threshold, determination of weight scheme, and aggregating and scoring. But in this paper, the researchers show only the main framework of BGH and the identification of two main sub-groups of the assessment tool, the main domains, and indicators that could be used in the future when the Business Gross Happiness Index will be designed. So, researchers' work in this paper could be defined as identification step of the above-mentioned methodology.

In the text below the authors try briefly to describe the influence and roles of the 9 main domains of BGH on companies in the tourism sector and the advantages and positives of practices of adopting Sustainable tourism management.

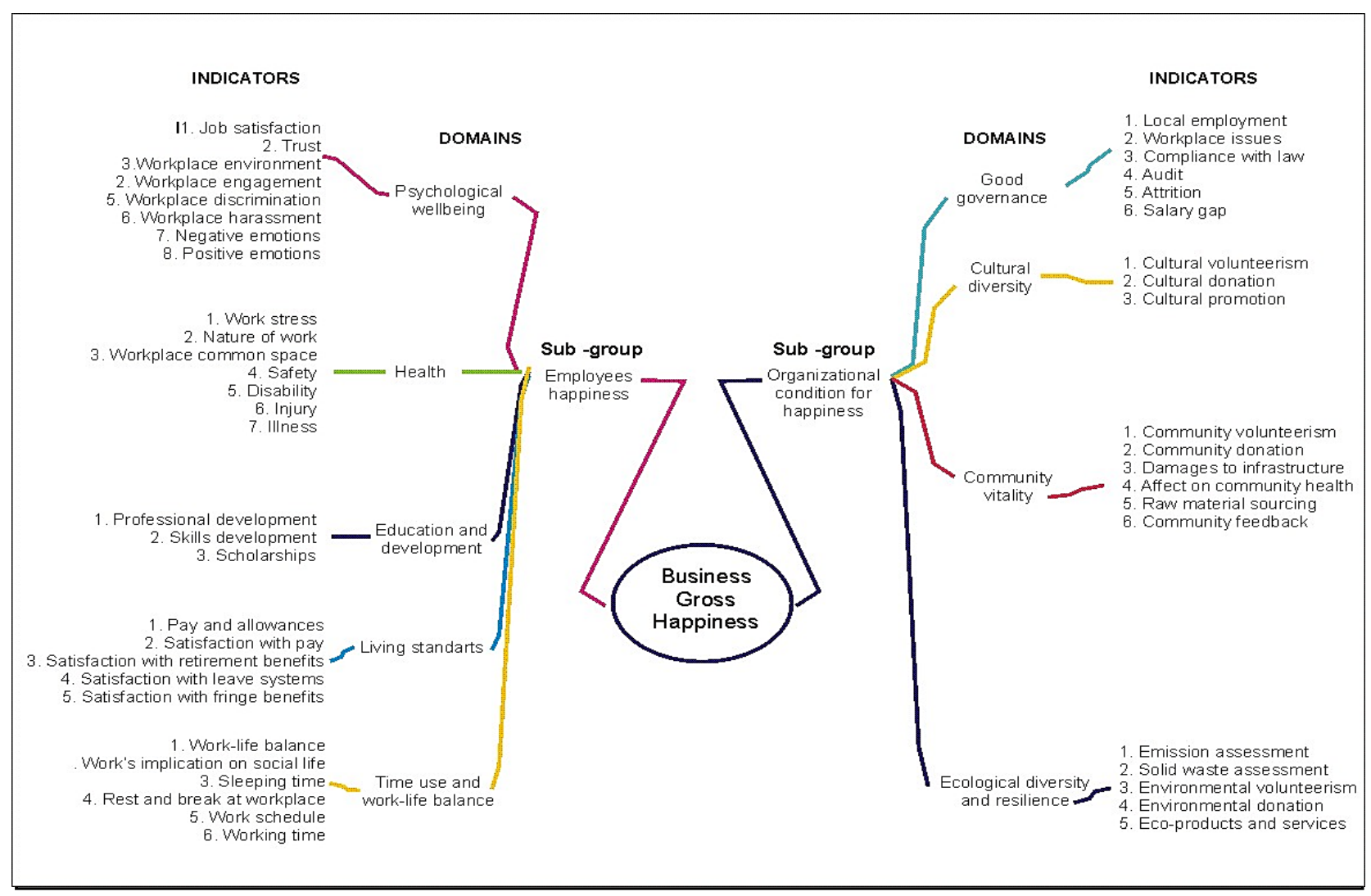

Figure 3. Business Gross Happiness framework

(Source: Utilized and adapted from Ura et al., 2012 and Verma, 2017)

Today's worker happiness is associated with better productivity, while managers have new perspective on wellbeing and happiness as leading indicators of performance (De Neve et al., 2013; De Neve \& Ward, 2017; Sgroi et al., 2017). And based on the above mentioned approach, it could be inferred that when the concept of wellbeing merges with business, 
money paid on initiatives for increasing workers' wellbeing is often accepted as an investment to increase productivity (Bryson et al., 2015). Thus, it might dominate as the core concept of GNH, which considers workers' happiness as one of the end goals rather than using happy workers to yield profit. In the strictest sense, the businesses that choose to integrate the GNH concept have to avoid viewing everything in terms of economic value and start considering their societal value (Zangmo et al., 2017). In this line of thought, managers can invest and encourage employees to seek and experience happiness at the workplace. As happiness is one of the most basic human pursuits (Graham, 2014), employees' happiness is a vital component to be integrated into the tool. There are a lot of work-related factors that could affect employee happiness. Some of them could be grouped as physical components such as good pay, benefits and training opportunities that can lead to a strong sense of happiness (Jobstreet, 2017; Joo \& Lee, 2017). Other unseen subjective components, such as the

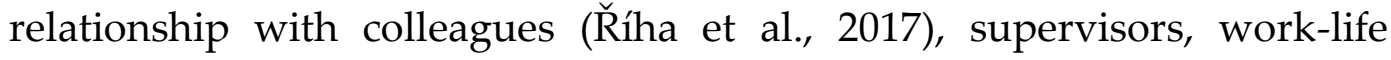
balance, etc., can provide additional insights on the workforce happiness (Fisher, 2010; Keser, 2016; Sousa \& Porto, 2015). Due to these reasons, employees' happiness is the first sub-group in the BGH framework that the authors discuss and draw the importance of it. The construct could be conceptualized and measured through a set of tangible and intangible factors across the five domains of psychological wellbeing, health, time use, education and living standards.

The psychological wellbeing domain contains indicators for the mental and physical experience at the workplace. It captures cognitive judgments and affective feelings of the employees and could be measured through 8 indicators: job satisfaction, trust, workplace environment, workplace engagement, discrimination and harassment, positive and negative emotions. Business management can treat company members like a family and this could help for improving the psychological wellbeing of employees (Bryson et al., 2015). Employee-oriented STM could consult, include, and listen to the organization members when they take important decisions. This kind of close relationship strengthens trust and increases the level of satisfaction among members of the teams and employees at companies (Pai \& Krishnan, 2015; Rosengren, 2018; Sulakhe \& Bakre, 2019). The advantage of members' regular interactions ensures better communication, networking and trust among teams and colleagues. So this kind of close-knit platform can contribute to reducing workplace discrimination (Prasad, 2017; Singh \& Aggarwal, 2018). Sustainable tourism management could minimize stress related to unemployment and also enhance employees' job satisfaction 
(Bakotić, 2016). As per the results of studies conducted in the UK and Australia, by Robert Half company, feelings appreciated are one of the top drivers of happiness, alongside being treated with fairness and respect at the workplace. Feeling appreciated is particularly important to employees and it is the strongest determinant of happiness for workers, as per the above-mentioned studies in both countries (Henry \& Pink, 2016, 2017).

Above mentioned papers and studies show us the important role that STM could play at the Business organization level in improving employee's psychological wellbeing, which is one of the main domains of the BGH framework. The second domain in employees' happiness subgroup that could be discussed is health.

Health domain could be measured trough 7 indicators (see Fig.3). Some authors discussed that STM at the organization level could improve employees' physical and mental health, thereby the authors could address "health" as a dimension of the BGH framework. Good STM could redound to reducing the mental stress of employees with frequent interactions among colleagues (Keser, 2016). One of the possible arguments for it is that members discuss solutions to their problems like a family, so this sense of belonging among the colleges have a positive influence on their (perceived in some instances) health (Rego et al., 2010; Şahin, 2018). STM has an opportunity to create awareness on health issues during gathering among employees (Esmail \& Shili, 2018), to improve the public health, and boost household income by creating employment opportunities (Pratt et al., 2016; Şahin, 2018; Sulakhe \& Bakre, 2019). Reviewed studies show the potentials of STM to improve health and on this basis have an important role in optimizing GNH as health determines the happiness of employees (Centre for Bhutan Studies \& GNH, 2017).

Time use and work-life balance domain could be measured via 6 indicators. Different studies show the correlation between working hours and employees' jobs satisfaction (Chophel \& Ura, 2018; Oswald et al., 2014). In this regards business organizations could have flexible working hours so this would allow employees to have more time for meeting family, education, leisure, social commitments (De Neve \& Ward, 2017; Fisher, 2010) and allow workers to have a good work-life balance.

Education domain. STM could educate their employees and at the same time give them opportunities to improve other sides of their life necessary for happiness, but they could vary depending on different personalities because every person has his/her definition and 
understanding of happiness. This domain could be measured via 3 indicators as visible on fig. 3

Living standards domain could be measured trough 5 indicators. STM has the potential to improve people's standard of living, therefore, different countries promote tourism as the main driver of the nation's development. Sustainable tourism can generate employment opportunities in the community, enabling people to earn decent incomes (European Commission, 2016; Wu et al., 2019), reduce poverty and improve people's standard of living (UNWTO, 2018).

Overall, the authors could recap the following:

a) Employees' happiness construct includes 5 domains and 29 indicators that provide insights on workplace commitment and opportunities to improve the working conditions.

b) Worker happiness is aimed at instilling a duty of care for worker's welfare. A significant association has been observed between workplace happiness and overall life quality (Schulte et al., 2015).

c) Worker happiness is an essential component for integrating GNH into business for several reasons. First, the conventional wisdom for an economy to disregard worker's emotional, social and spiritual needs does not hold any longer (Demircioglu, 2014; Fisher, 2010), and second, there is a need to integrate ecological and social values into business to capture the full range of human values and needs at the workplace (Green et al., 2016; Mendlewicz, 2019). People spend a long time at work, especially in the tourism sector, so the balance between workplace and personal life is very important and events experienced at workplace influence events in non-work life (De Neve \& Ward, 2017). Meanwhile, the working environment could evolve and this changing environment could bring the drive to align employees' personal and professional life.

Depending on the above-discussed issues, it is objective to review and discuss what could be the organizational conditions for happiness. They are accepted as a second sub-group of domains in BGH. This construct includes good governance, cultural diversity, community vitality and ecological diversity domains.

Good governance domain in this context includes the ST values and principles which go together with other national and international specific laws regarding the tourism industry. Individuals that take leadership responsibilities have the opportunity to learn specific skills, knowledge and 
behavior necessary for governing groups and organizations (Demircioglu, 2014; Southworth, 2013; Tideman, 2016). Education and training programs provided by the company, such as leadership, office management and others, could also enhance their governing skills. STM can make policy recommendations for the benefit of wider communities (Alfaro Navarro et al., 2019; Blancas et al., 2015; UNWTO, 2017). STM guided by principles of GNH could optimize and promote good governance at organizational, local and national levels. This domain could be measured via 6 indicators (Figure 3).

Cultural diversity domain. In the tourism sector employees are very different in their ethnicity, language, nationality, religion and gender (Fisher, 2010; Mujtaba et al., 2016). The management of the sustainable tourism companies has opportunity to work with different ethnic groups and the interaction of employees with different culture during tourist stay, team building/training, and other learning activities promote cultural diversity in the organization. In this regard, the researchers claim that ST plays a significant role in the preservation and promotion of culture $(\mathrm{He}$, et al., 2018; Nezakati \& Hosseinpour, 2014; Pratt, et al., 2016). Similarly, there are other forms of sustainable tourism dealing with conventional local products preserving and promoting culture (Goni \& Yustika, 2019). Such community-friendly organizations can develop traditional knowledge through trial and error (Schroeder, 2015). Further, ST can preserve and pass traditional knowledge to future generations. These social capitals through cultural participation are more stable and help to develop strong relations across differences in the communities. The cultural diversities among employees of ST strengthen the social relationship, which is vital for optimizing sustainability and BGH, and this domain could be measured trough 3 indicators.

Community vitality domain could be measured via 6 indicators. Important indicators of community vitality are social support, community relationship and community security (Musikanski et al., 2017; Vikash, 2019). ST shares resources, ensures access to markets and prevents discrimination in the market (Kisi, 2019). The interactive environment, necessitated by interdependence at all levels of ST companies, fosters the sense of belonging among people (Schinzel, 2013). The community-based engagement of people through ST implies a peaceful society based on the principles of interdependence, reciprocity, mutual benefit and peaceful coexistence (Dangi \& Jamal, 2016). "Concern for the community" could be accepted as one of the ST principles. Employees and teams that often engage in voluntary activities contributes to improving people's well-being. The 
vibrancy and vitality of community life are indispensable in optimizing GNH. Last but not least, the authors have to review the ecological diversity domain.

Ecological diversity domain. ST incorporates a wide range of activities, including ecotourism, green tourism, rural and agro-tourism, community tourism, solidarity and responsible tourism, all these opposing to the traditional, mass tourism (He et al., 2018; Nezakati \& Hosseinpour, 2014). Thus, ST attempts to harmonize the human-environment interactions by adopting the Triple Bottom Line that considers people, planet and profit (Wu et al., 2019). STM could also enable people to find innovative solutions to environmental changes by allowing them to diversify their economic activities and embrace more green and innovative practices (Fernando et al., 2019; Marcon et al., 2016; Nezakati \& Hosseinpour, 2014). The emerging importance of using renewable energy in ST is highlighted in some papers (Petit, 2019; Union for the Mediterranean, n.d.), by enabling the world societies to move forward in the global quest to curtail the carbon emission and use of fossil fuels. In socio-political respects (Lee et al., 2015), STM facilitates environmental policy formulation, endorsement and achievement of the policy goals through diligent implementation of these policies in their activities and localities (Drius et al., 2018; Kisi, 2019; Kraleva et al., 2020). These examples allow us to address STM to BGH domain of ecological diversity and resilience, and this domain could be measured trough 6 indicators (see Figure 3).

The proposed framework allows managers to see organizational conditions for happiness, the level of penetration of GNH values in their corporate philosophy, allow them to see what is the level of acceptance and adaptation of GNH principles, and show the advantages of the GNH on the business culture. This could lead to a strong business culture- that attracts customers and employees, in a way that any advertising cannot. A strong culture is resistant, agile, and able to survive in difficult times. BGH could be a sign of the cultural health of the company. It could also help managers to reinforce happiness skills and prepare a strategic plan in accordance with them. It could be a barometer for employees' motivation for work and could allow them to do their job sustainably. In order to have a happy organization, we have to measure the right thing and to strive to have happy employees as happiness could be sustainable. 


\section{CONCLUSIONS AND RECOMMENDATIONS FOR FUTURE RESEARCH}

Tourism is a complex sector by nature, consisting of multiple actors with diverse interests. Companies met different challenges in resource consumption, environmental pollution, policymaking and implementation in connection with SD. One of the main obstacles to achieving SD is the difficulty of measuring the level of sustainability achieved by companies in the sector, destinations, etc. Although there are no universally-accepted lists of indicators, the usage of discussed tools as a measure of sustainability has become widespread in recent years. However, the application of these tools in the tourism sector is not effortless given the lack of a clear definition of the concept of sustainable tourism. It plays a big role in environmental conservation and driving to socioeconomic development which is mentioned in several of the SDGs. STD guidelines and management practices are applicable to all forms of tourism in all types of destinations. Sustainability principles refer to the environmental, economic and sociocultural aspects of tourism development, and an appropriate balance must be established between these three dimensions to guarantee its long-term sustainability. In this regard and based on UNWTO definition for ST the researchers could summarize: STM could optimally use the environmental resources that constitute a key element in tourism development, maintaining essential ecological processes and helping to conserve natural heritage and biodiversity. Another very important topic regarding STM is that the companies in the sector have to respect the socio-cultural authenticity of host communities, to conserve their built and living cultural heritage and traditional values, and to contribute to intercultural understanding, tolerance and happiness. STM has to do its best to ensure sustainable long-term economic operations, providing socio-economic benefits to all stakeholders that are fairly distributed, including stable employment and income-earning opportunities and social services to host communities, and contributing to poverty alleviation. STD requires informed participation of all relevant stakeholders, as well as strong political leadership to ensure wide participation and consensus-building. Achieving ST is an endless process and it requires monitoring of impacts, introducing the necessary preventive and/or corrective measures whenever necessary.

Referring to above-discussed issues and intersection between SD, ST, the wellbeing of the community, GNH and BGH (that is summarized by the authors in Table 3.), the authors could say all of them have same cross points of three main pillars - social, environmental and economic. Based on that 
inference, the Table 3 visualizes the relations of the proposed $\mathrm{BGH}$ framework and its domains to the ST, SD, the wellbeing of the community and the GNH.

Table 2. The relations among SD, ST, Wellbeing of community sustainability, GNH and BGH

\begin{tabular}{|c|c|c|c|c|c|}
\hline \multirow[b]{2}{*}{$\begin{array}{l}\text { Sustainable } \\
\text { development }\end{array}$} & \multirow{2}{*}{$\begin{array}{l}\text { Sustainable } \\
\text { tourism }\end{array}$} & \multirow{2}{*}{$\begin{array}{l}\text { Wellbeing of } \\
\text { community } \\
\text { sustainability }\end{array}$} & \multirow[b]{2}{*}{ GNH pillars } & \multicolumn{2}{|c|}{ BGH framework } \\
\hline & & & & $\begin{array}{c}\text { Domains of } \\
\text { BGH }\end{array}$ & Sub-groups \\
\hline \multirow{5}{*}{$\begin{array}{c}\text { Social } \\
\text { progress }\end{array}$} & \multirow{5}{*}{$\begin{array}{c}\text { Socio- cultural } \\
\text { sustainability }\end{array}$} & \multirow{4}{*}{ Cultural } & \multirow{4}{*}{$\begin{array}{c}\text { Culture } \\
\text { (preservation } \\
\text { of culture) }\end{array}$} & $\begin{array}{c}\text { Time use and } \\
\text { work-life balance }\end{array}$ & $\begin{array}{l}\text { Employee } \\
\text { happiness }\end{array}$ \\
\hline & & & & $\begin{array}{c}\text { Community } \\
\text { vitality }\end{array}$ & $\begin{array}{c}\text { Organizational } \\
\text { conditions } \\
\text { for happiness }\end{array}$ \\
\hline & & & & Cultural resilience & $\begin{array}{l}\text { Organizational } \\
\text { condition } \\
\text { for happiness }\end{array}$ \\
\hline & & & & $\begin{array}{l}\text { Wellbeing } \\
\text { (psychological } \\
\text { wellbeing) }\end{array}$ & $\begin{array}{l}\text { Employee } \\
\text { happiness }\end{array}$ \\
\hline & & Social & $\begin{array}{c}\text { Society (good } \\
\text { governance) }\end{array}$ & Good governance & $\begin{array}{c}\text { Organizational } \\
\text { conditions } \\
\text { for happiness }\end{array}$ \\
\hline \multirow{3}{*}{$\begin{array}{c}\text { Economic } \\
\text { development }\end{array}$} & \multirow{3}{*}{$\begin{array}{c}\text { Economic } \\
\text { sustainability }\end{array}$} & \multirow{3}{*}{ Economic } & \multirow{3}{*}{$\begin{array}{c}\text { Economy } \\
\text { (sustainable, } \\
\text { equitable economic } \\
\text { development) }\end{array}$} & Health & $\begin{array}{l}\text { Employee } \\
\text { happiness }\end{array}$ \\
\hline & & & & $\begin{array}{c}\text { Education and } \\
\text { development }\end{array}$ & $\begin{array}{l}\text { Employee } \\
\text { happiness }\end{array}$ \\
\hline & & & & Living standards & $\begin{array}{l}\text { Employee } \\
\text { happiness }\end{array}$ \\
\hline $\begin{array}{c}\text { Environmental } \\
\text { responsibility }\end{array}$ & $\begin{array}{c}\text { Environmental } \\
\text { sustainability }\end{array}$ & Environmental & $\begin{array}{c}\text { Environment } \\
\text { (conservation of } \\
\text { environment) }\end{array}$ & $\begin{array}{l}\text { Ecological } \\
\text { diversity }\end{array}$ & $\begin{array}{c}\text { Organizational } \\
\text { conditions for } \\
\text { happiness } \\
\end{array}$ \\
\hline
\end{tabular}

Largely, ST plays a significant role in delivering solutions to problematic issues through the framework of all 17 SDGs. Based on the connection with SDGs and General assembly resolution 70/193, 2017 year was declared as the "International Year of Sustainable tourism development". Based on the above-discussed issues, Figure 1, Figure 2 and Table 3 relations between the pillars of sustainability, ST, happiness and distribution of SDGs could clearly be seen. Happiness and wellbeing are related to the social sustainability pillar and with increased interest in happiness as a global measure of success on a national and international level, it could be used as an appropriate concept for STM. In this paper, the authors discussed the conceptual framework of STD and tried to propose a holistic approach for STM following SDGs, the GNH concept and covering all aspects of sustainability. Referring to discussed matters regarding ST and assessment tools, the proposed adaptation of GNH values in business organizations in the sector will help them to change the current 
unsustainable model of business management in a holistic way. The proposed BGH framework could help managers oversee what are organizational conditions and issues which contribute to employees' happiness and happiness of the organization as a whole and to help them to do their best in the achievement of the SDGs of Agenda 2030 for SD. Based on reviewed studies, the authors could also assert that STM has the potential to improve and optimize its business by using BGH framework, by improving workers' happiness and organizational conditions for happiness. Unlike other profit-driven business models, companies that would adopt BGH will have the ability to achieve not only economic benefits, but also such for the environment, socio-culture and good governance.

This research, based on previous studies, allows authors to see the positive impacts of the GNH concept on STM, but there is a need for further empirical studies to test the above-mentioned discussions. This study could inspire researchers in the future to study STM empirically through the lens of GNH by the BGH framework proposed in this study in the context of business organizations in tourism. Adoption GNH values in the company's goals will help them to go through completing SDGs of Agenda 2030 and will help them to achieve profits sustainably and holistically.

As a conclusion of this paper, the researchers can summarize that the current unsustainable business practices of tourism firms have conflicts between balancing economic growth and environmental impacts. There are inconsistencies between academics' researches and their findings, and implementations in the sector, which reflect the need for collaboration between researchers and businesses in order to realize researchers' recommendations and study results in STM. The authors hope that this work will inspire other colleagues to use the proposed BGH framework for empirical tests in order to examine the gap between scholarly works and real application into the business. In this regard, the authors could recommend the $\mathrm{BGH}$ framework to be adopted for Bulgarian companies and to be used as an assessment tool that will help the management to apply STM on the local and regional levels.

\section{REFERENCES}

Aall, C. (2014). Sustainable tourism in practice: Promoting or perverting the quest for a sustainable development? Sustainability 6(5), 2562-2583. https://doi.org/10.3390/su6052562

Adams, W. M. (2006). The future of sustainability. Re-thinking environment and development in the twenty-first century. In Report of the IUCN Renowned Thinkers 
Meeting.

Retrieved

from

hhttp://www2.ecolex.org/server2neu.php/libcat/docs/LI/MON-075076.pdf

Alfaro Navarro, J. L., Andrés Martínez, M. E., \& Mondéjar Jiménez, J. A. (2019). An approach to measuring sustainable tourism at the local level in Europe. Current Issues in Tourism, 23(4), 423-437 https://doi.org/10.1080/13683500.2019.1579174

Aureliano-Silva, L., de Oliveira, P. S. G., \& Alves, C. A. (2017). A relação entre a felicidade e o desejo por hospitalidade mediada pela autoimagem do turista e a imagem do seu destino. Revista Brasileira de Pesquisa Em Turismo, 11(3), 436-453. https://doi.org/10.7784/rbtur.v11i3.1324

Baker, J. (2015). The rise of the conscious consumer: why businesses need to open up, Women in Leadership, The Guardian. Retrieved May 21, 2019, from theguardian.com website: https:/www.theguardian.com/women-inleadership/2015/apr/02/the-rise-of-the-conscious-consumer-why-businessesneed-to-open-up

Bakotić, D. (2016). Relationship between job satisfaction and organisational performance. Economic REsEaRch-Ekonomska IstRaživanja, 29(1), 118-130. https://doi.org/10.1080/1331677X.2016.1163946

Bimonte, S., \& Faralla, V. (2016). Does residents' perceived life satisfaction vary with tourist season? A two-step survey in a Mediterranean destination. Tourism Management, 55, 199-208. https://doi.org/10.1016/j.tourman.2016.02.011

Blancas, F. J., Lozano-Oyola, M., \& González, M. (2015). A European Sustainable Tourism Labels proposal using a composite indicator. Environmental Impact Assessment Review, 54, 39-54. https://doi.org/10.1016/j.eiar.2015.05.001

Boley, B. B., McGehee, N. G., \& Hammett, A. L. T. (2017). Importance-performance analysis (IPA) of sustainable tourism initiatives: The resident perspective. Tourism Management, 58, 66-77.

Bryson, A., Forth, J., \& Stokes, L. (2015). Does Worker Wellbeing Affect Workplace Performance? Retrieved October 13, 2020, from http://ftp.iza.org/dp9096.pdf

Buckley, R. (2012). Sustainable Tourism: Research and Reality. Annals of Tourism Research, 39(2), 528-546. https://doi.org/10.1016/j.annals.2012.02.003

Centre for Bhutan Studies, \& GNH. (2017). Health, happiness and wellbeing; Implications for public policy. In Happiness Transforming the Development Landscape. Retrieved from http://www.bhutanstudies.org.bt/wp-content/uploads/2017/05/Happinesstransform_Final_with-cover.pdf

Chen, Y. (2016). The Swiss tourist happiness index. Retrieved October 13, 2020, from The Swiss Tourist Happiness Index website: https://hospitalityinsights.ehl.edu/swisshospitality-and-tourism-index

Choi, H. C., \& Murray, I. (2010). Resident attitudes toward sustainable community tourism. Journal of Sustainable Tourism, 18(4), 575-594. https://doi.org/10.1080/09669580903524852

Chophel, S., \& Ura, D.K. (2018). GNH of Business. In D. Karma and S. Chohel (Eds.), Proceedings of the Seventh International Conference on Gross National Happiness, 7-9 November, 2017. Retrieved June 10, 2020, from https://www.bhutanstudies.org.bt/gnh-of-business-proceedings-of-the-seventhinternational-conference-on-gross-national-happiness/

Cloutier, S., \& Pfeiffer, D. (2015). Sustainability Through Happiness: A Framework for Sustainable Development. Sustainable Development, 23(5), 317-327. https://doi.org/10.1002/sd.1593 
Coffey, J. K., Warren, M. T., Gottfried, A. W., Coffey, J. K., Warren, Á. M. T., \& Gottfried, A. W. (2015). Does Infant Happiness Forecast Adult Life Satisfaction? Examining Subjective Well-Being in the First Quarter Century of Life. J Happiness Stud, 16, 1401-1421. https://doi.org/10.1007/s10902-014-9556-x

Copley, P. (2011). David Cameron's Wellbeing Index could mean happiness is the next big thing. EG: Estates Gazette, 1136, 60-61.

Crabtree, A., \& Gasper, D. (2020). Conclusion: The sustainable development goals and capability and human security analysis. In A. Crabtree (Ed.), Sustainability, Capabilities and Human Security (pp. 169-182). https://doi.org/10.1007/978-3-03038905-5_7

Croes, R., Rivera, M. A., \& Semrad, K. J. (2017). 2016 Happiness Survey: Aruba Happiness E Tourism". Retrieved October 13, 2020, from Dick Pope Sr. Institute Publications website:https://stars.library.ucf.edu/cgi/viewcontent.cgi?referer=https://www.goo gle.com/\&httpsredir=1\&article=1040\&context=dickpope-pubs

Dangi, T. B., \& Jamal, T. (2016). An integrated approach to "sustainable community-based tourism" Sustainability, 8(5), 475. https://doi.org/10.3390/su8050475

De Neve, J. E., Diener, E., Tay, L., \& Xuereb, C. (2013). The objective benefits of subjective wellbeing. In Helliwell, J., Layard, R., \& Sachs, J., eds. World Happiness Report 2013 (Vol. 2, pp. 54-79). New York: UN Sustainable Development Solutions Network.

De Neve, J. E., \& Ward, G. (2017). Does work make you happy? Evidence from the world happiness report. Harvard Business Review, 4, 1-7. Retrieved from https://hbr.org/2017/03/does-work-make-you-happy-evidence-from-the-worldhappiness-report

Demircioglu, E. (2014). Organization performance and happiness in the context of leadership behavior. International Research Journal of York University, 1(1), 47-72. Retrieved from http://mpra.ub.uni-muenchen.de/61484/

Dendup, T., Prasad, B., Acharja, I. L., Dendup, T., \& Zangpo, S. (2018). Review on the Role of Agriculture Cooperatives in Optimising Gross National Happiness. Journal of Economics, Management and Trade, 21(9), 1-8. https://doi.org/10.9734/jemt/2018/43992

Drius, M., Bongiorni, L., Depellegrin, D., Menegon, S., Pugnetti, A., \& Stifter, S. (2018). Tackling challenges for Mediterranean sustainable coastal tourism: An ecosystem service perspective. Science of The Total Environment, 652, 1302-1317. https://doi.org/10.1016/j.scitotenv.2018.10.121

Elkington, J. (1997). Enter the Triple Bottom Line. Retrieved October 07, 2020, from http://www.johnelkington.com/archive/TBL-elkington-chapter.pdf

Epstein, M., \& Buhovac, A. (2014). Making Sustainability Work: Best Practices in Managing and Measuring Corporate, Environmental, and Economic Impacts. In Ecological Economics. $\quad$ Retrieved June 01, 2020, from https://www.bkconnection.com/static/Making_Sustainability_Work_2nd_EXCER PT.pdf

Erkuş-Öztürk, H., \& Eraydin, A. (2010). Environmental governance for sustainable tourism development: Collaborative networks and organisation building in the Antalya tourism region. Tourism Management, 31(1), 113-124. https://doi.org/10.1016/j.tourman.2009.01.002

Esmail, H. A. H., \& Shili, N. N. J. (2018). The relationship between happiness and economic development in KSA: Study of Jazan Region. Asian Social Science, 14(3), 78-87. https://doi.org/10.5539/ass.v14n3p78 
European Commission. (2016). Study on specific challenges for a sustainable development of coastal and maritime tourism in Europe. https://doi.org/10.2826/94993

Fernando, Y., Jasmi, M. F. A., \& Shaharudin, M. S. (2019). Maritime green supply chain management: Its light and shadow on the bottom line dimensions of sustainable business performance. International Journal of Shipping and Transport Logistics, 11(1), 60-93. https://doi.org/10.1504/IJSTL.2019.096872

Firoiu, D., Ionescu, G. H., Băndoi, A., Florea, N. M., \& Jianu, E. (2019). Achieving Sustainable Development Goals (SDG): Implementation of the 2030 Agenda in Romania. Sustainability, 11(7), 2156. https://doi.org/10.3390/su11072156

Fisher, C. D. (2010). Happiness at Work. International Journal of Management Reviews, 12(4), 384-412. https://doi.org/10.1111/j.1468-2370.2009.00270.x

Gil-Saura, I., \& Ruiz-Molina, M.-E. (2019). Sustainable Practices in Spanish Hotels: A Response to Concerns on Quality of Life in Highly Visited Tourism Areas. In A. Campón-Cerro, J. Hernández-Mogollón, J. Folgado-Fernández (Eds), Best Practices in Hospitality and Tourism Marketing and Management, Applying Quality of Life Research (pp. 201-216). https://doi.org/10.1007/978-3-319-91692-7_10

Goni, J. I. C., \& Yustika, B. P. (2019). The Presence of Global Value Chain in Coastal Marine Tourism. Jurnal Riset Manajemen Dan Bisnis (JRMB) Fakultas Ekonomi UNIAT, 4(1), 137-152. Retrieved from http://jrmb.ejournalfeuniat.net/index.php/JRMB/article/view/248

Graham, C. (2014). In Pursuit of Happiness. https://doi.org/10.1093/acprof:osobl/9780199549054.001.0001

Green, F., Felstead, A., Gallie, D., \& Inanc, H. (2016). Job-Related Well-Being Through the Great Recession. Journal of Happiness Studies, 17(1), 389-411. https://doi.org/10.1007/s10902-014-9600-x

Habibullah, M. S., Din, B. H., Chong, C. W., \& Radam, A. (2016). Tourism and Biodiversity Loss: Implications for Business Sustainability. Procedia Economics and Finance, 35, 166-172. https://doi.org/10.1016/s2212-5671(16)00021-6

Hadi, N. U., Ananda, C. F., \& Khusaini, M. (2018). The happiness index as a new and complementary measurement of development as applied to each province of Indonesia. International Journal of Economics and Financial Issues, 8(4), 214-221.

Hardy, A., \& Pearson, L. J. (2018). Examining stakeholder group specificity: An innovative sustainable tourism approach. Journal of Destination Marketing $\mathcal{E}$ Management, 8, 247-258. https://doi.org/10.1016/j.jdmm.2017.05.001

Hatipoglu, B., Alvarez, M. D., \& Ertuna, B. (2016). Barriers to stakeholder involvement in the planning of sustainable tourism: the case of the Thrace region in Turkey. Journal $\begin{array}{lllll}\text { of cleaner } & \text { production } & \text { 306-317. }\end{array}$ https://doi.org/10.1016/j.jclepro.2014.11.059

He, P., He, Y., \& Xu, F. (2018). Evolutionary analysis of sustainable tourism Sustainable tourism Greenpreference Green Innovation Government incentive mechanism Evolutionary game theory. Annals of Tourism Research, 69, 76-89. https://doi.org/10.1016/j.annals.2018.02.002

Helliwell, J. F., Layard, R., \& Sachs, J. D. (2018). World Happiness Report 2018. Retrieved June 05, 2020, from http://worldhappiness.report/ed/2018/

Henry, T., \& Pink, D., (2016). It's time we all work happy. Robert Half Personal Rekruting. Retrieved May 01, 2020, from https://www.roberthalf.com.au/sites/roberthalf.com.au/files/documents/Robert\% 20Half\%20It\%27s\%20time\%20we\%20all\%20work\%20happy.pdf 
Henry, T., \& Pink, D., (2017). The secret of the happiest companies and employees. Retrieved May 10, 2020, from https://www.roberthalf.co.uk/sites/roberthalf.co.uk/files/pdf/noindex/robert-halfunited-kingdom-its-time-we-all-work-happy-2017.pdf

Jhamb, A. (2019). Corporate Social Responsibility in Tourism Industry. In Corporate Social Responsibility: Concepts, Methodologies, Tools, and Applications (pp. 49-54). https://doi.org/10.4018/978-1-5225-6192-7.ch003

Jobstreet. (2017). Employee Job Happiness Index 2017: Strategies to Engage, Motivate and Retain Top Talent. SEEK Asia Signature Market Research Series 4, 1-24. Retrieved February 2, 2020, from https://www.jobstreet.com.my/announcement/FTP/Job_Happiness_Index_2017_1 7_Jan.pdf

Joo, B. K., \& Lee, I. (2017). Workplace happiness: work engagement, career satisfaction, and subjective well-being. Evidence-Based HRM, 5(2), 206-221. https://doi.org/10.1108/EBHRM-04-2015-0011

Juvan, E., \& Dolnicar, S. (2014). The attitude-behaviour gap in sustainable tourism. Annals of Tourism Research, 48, 76-95. https://doi.org/10.1016/j.annals.2014.05.012

Kaushal, V., \& Sharma, S. (2016). Corporate social responsibility in tourism and hospitality: Relationships and Applications. In L. K. Guliani \& S. A. Rizwan (Eds), Corporate Social Responsibility in the Tourism and Hospitality Industry (pp. 144-161). IGI Global.

Keeble, B. R. (1988). The Brundtland Report: "Our Common Future." Medicine and War, 4, 17-25. https://doi.org/10.1080/07488008808408783

Keser, A. (2016). Happiness at work: Survey from Turkey. The 2016 International Academic Research Conference in London -Zurich 345, 295-301. Retrieved from http://www.ijbts-journal.com/images/column_1468911104/Binder6(Tract6)8797.pdf

Kisi, N. (2019). A Strategic Approach to Sustainable Tourism Development Using the A'WOT Hybrid Method: A Case Study of Zonguldak, Turkey. Sustainability, 11(4). https://doi.org/10.3390/su11040964

Kraleva, V., \& Ivanov, S. (2018). Towards a general model of sustainable involvement. In proceedings of 10th International Scientific Conference "New Challenges of Economic and Business Development - 2018: Productivity and Economic Growth" (pp. 358 - 366). May 10 - 12, 2018, Riga, University of Latvia.

Kraleva, V., Ivanov, S., Maric, R. (2020). Zones of activism and sustainable consumption Insights from Bulgaria, Romania and Serbia. Journal of Sustainable Development, 10(24), 66-78.

Lee, A. H. I., Chen, H. H., \& Chen, S. (2015). Suitable organization forms for knowledge management to attain sustainable competitive advantage in the renewable energy industry. Energy, 89, 1057-1064. https://doi.org/10.1016/j.energy.2015.06.047

Lee, T. H. (2013). Influence analysis of community resident support for sustainable tourism development. Tourism Management, 34, 37-46. https://doi.org/10.1016/j.tourman.2012.03.007

Liu, K. K. (2013). Happiness and Tourism. International Journal of Business and Social Science, 4(15), 67-70. Retrieved from www.ijbssnet.com

Lohmann, M., \& De Bloom, J. (2015). Happiness in a tourism context. International Conference on Gross National Happiness on GNH. Retrieved from http://www.bhutanstudies.org.bt/2015GNHConference/Paperfor2015GNHConfer ence/12.Happiness Tourism GNH conference paper 2015 05.pdf 
Lukina V., Zhechev V., \& Niyazieva. S. (2020). New Challenges and Prospects for Marketers in Companies. In A. V. L. I. Skorobogatykh (Ed.), Materials of the VIII AllRussian Scientific-Practical conference "Plekhanov forum of teachers." "The joint creation of value in the university in the digital age: the development of subject areas: the role of teachers and students", 12 December 2019 (pp. 169-172). Moscow: FSBEI HE "REU named after G. V. Plekhanov" 2020. Collection of the 8th Plekhanov forum of teachers, 2020.

Malindretos, G. (2013). Know - How and Sustainability. Innovation and Sustainability in Maritime Transport: Green Shipping, (May 2013).

Marcon, A., de Medeiros, J. F.., \& Ribeiro, J. L. D., (2016). Innovation and environmentally sustainable economy: Identifying the best practices developed by multinationals in Brazil. Journal of Cleaner Production, 160, 83-97. https://doi.org/10.1016/j.jclepro.2017.02.101

Martin, D., \& Schouten, J. (2012). Marketing in the Twenty-First Century. New York: Pearson Prentice Hall.

McCabe, S., \& Johnson, S. (2013). The happiness factor in tourism: Subjective well-being and social tourism. Annals of Tourism Research, 41, 42-65. https://doi.org/10.1016/j.annals.2012.12.001

Mendlewicz, D. (2019). Employee Happiness Leads to Business Success - Management Coaching from Employee Feedback Butterfly AI. Retrieved August 07, 2019, from https://www.butterfly.ai/employee-happiness-leads-to-business-success/

Moscardo, G. (2008). Sustainable tourism innovation: Challenging basic assumptions. Tourism and Hospitality Research, 8(1), 4-13. https://doi.org/10.1057/thr.2008.7

Mujtaba, B. G., Wayne, H., Cavico, F. J., \& Senathip, T. (2016). Sustainable Operational Management for Effective Leadership and Efficiency in the Modern Global Workplace. International Journal of Recent Advances in Organizational Behaviour and Decision Sciences (IJRAOB) An Online International Research Journal, 2(2), 2311-3197.

Musikanski, L., Cloutier, S., Bejarano, E., Briggs, D., Colbert, J., Strasser, G., \& Russell, S. (2017). Happiness Index Methodology. The journal of Social Change 9(1), 4-31. https://doi.org/10.5590/JOSC.2017.09.1.02

NDP Steering Committee and Secretariat. (2013). Happiness: Towards a New Development Paradigm. Retrieved October 14, 2020 from http://www.penseesdemonrecif.org/images/inspirations/NDP_Report_Bhutan_20 13.pdf

Nezakati, H. \& Hosseinpour, M. (2014). Green Tourism Practices in Malaysia. In H. Hamimah \& H. Nezakati (Eds), Selected Issues in Hospitality and Tourism Sustainability (pp. 24-36). Serdang: Universiti Putra Malaysia Press.

Nielson. (2018). Global Consumers Seek Companies That Care About Environmental Issues. Retrieved May 11, 2019, from Nielsen website: https://www.nielsen.com/us/en/insights/news/2018/global-consumers-seekcompanies-that-care-about-environmental-issues.html

Niyazieva, S. (2020). Happiness - wind of change for shipping companies, a new way to measure their performance. Sustainable Development and Innovations in Marine Technologies - Proceedings of the 18th International Congress of the International Maritime Association of the Mediterranean, IMAM 2019, 488-495. https://doi.org/10.1201/9780367810085-65

Nokelainen, M. (2015). The elements of happy organizational culture. Retrieved January15, 2020 , 
https://www.theseus.fi/bitstream/handle/10024/109071/Theelementsofhappyorga nizationalculture.pdf?sequence $=1$

Olesen, S. F., \& Wiking, M. (2017). Job Satisfaction INDEX 2017. Retrieved October 14, 2020 from https://6e3636b7-ad2f-4292-b910faa23b9c20aa.filesusr.com/ugd/928487_f752364b0a43488c8c767532c0de4926.pdf

Oliveira, E. (2018). The Importance of Corporate Social Responsibility in the Development of Sustainable Tourism. In: D. Crowther, S. Seifi, \& T. Wond (Eds), Responsibility and Governance. Approaches to Global Sustainability, Markets, and Governance. Singapore: Springer. https://doi.org/10.1007/978-981-13-1047-8_8

Oswald, A. J., Proto, E., \& Sgroi, D. (2014). Happiness and Productivity. Retrieved October 10, 2020, from https://the-happiness-index.com/wpcontent/uploads/2016/09/Warwick-Study-into-Happiness-vs.-Productivity2014.pdf

Pai, A., \& Krishnan, V. R. (2015). Can Transformational Leadership Increase the Happiness Index in Organisations Through Empowerment? Journal of Organisation E Human Behaviour, 4(2/3), 22-28. https://doi.org/10.21863/johb/2015.4.2and3.009

Pan, S.-Y., Gao, M., Kim, H., Shah, K. J., Pei, S.-L., \& Chiang, P.-C. (2018). Advances and challenges in sustainable tourism toward a green economy. Science of the Total Environment, 635, 452-469. https://doi.org/10.1016/j.scitotenv.2018.04.134

Panwar, N., \& Singh Rautela, K. (2019). Mapping Sustainable Tourism into Emergency Management Structure to Enhance Humanitarian Networks and Disaster Risk Reduction Using Public-Private Partnerships (PPP) Initiatives in Himalayan States: The Global Supply Chain Issues and Strategies Mapping Sus. In Emergency and Disaster Management: Concepts, Methodologies, Tools, and Applications (pp. 11681190). https://doi.org/10.4018/978-1-5225-6195-8.ch054

Petit, V. (2019) Solutions for a Sustainable Transition. In: The New World of Utilities. Springer, Cham. https://doi.org/10.1007/978-3-030-00187-2_5

Prasad, J. S. D. (2017). Workforce diversity and its impact on work culture of Indian organisations. The Journal of Commerce, 4(1), 33-44.

Pratt, S., McCabe, S., \& Movono, A. (2016). Gross happiness of a "tourism" village in Fiji. Journal of Destination Marketing and Management, 5(1), 26-35. https://doi.org/10.1016/j.jdmm.2015.11.001

Precup, R. E., \& Hellendoorn, H. (2011). A survey on industrial applications of fuzzy control. Computers in Industry, 62, 213-226. https://doi.org/10.1016/j.compind.2010.10.001

Pulido-Fernández, J. I., Andrades-Caldito, L., \& Sánchez-Rivero, M. (2015). Is sustainable tourism an obstacle to the economic performance of the tourism industry? Evidence from an international empirical study. Journal of Sustainable Tourism, 23(1), 47-64. https://doi.org/10.1080/09669582.2014.909447

Pulido-Fernández, J. I., \& López-Sánchez, Y. (2016). Are tourists really willing to pay more for sustainable destinations? Sustainability, 8(12). https://doi.org/10.3390/su8121240

Ram, Y., Nawijn, J., \& Peeters, P. M. (2013). Happiness and limits to sustainable tourism mobility: A new conceptual model. Journal of Sustainable Tourism, 21(7), 1017-1035. https://doi.org/10.1080/09669582.2013.826233

Ramgulam, N., Raghunandan-mohammed, K., \& Raghunandan, M. (2013). Environmental sustainability in the $21^{\text {st }}$ century: An assessment of Trinidad's business tourism market. Review of Business and Finance Studies, 4(1), 51-62 
Rego, A., Ribeiro, N., \& Cunha, M. P. (2010). Perceptions of organizational virtuousness and happiness as predictors of organizational citizenship behaviors. Journal of Business Ethics, 93(2), 215-235. https://doi.org/10.1007/s10551-009-0197-7

Reineman, D. R., \& Ardoin, N. M. (2018). Sustainable tourism and the management of nearshore coastal places: place attachment and disruption to surf-spots. Journal of Sustainable Tourism, 26(2), 325-340. https://doi.org/10.1080/09669582.2017.1352590

Ř́ha, D., Heinze, T., \& Stros, M. (2017). Intercultural variations in personal sales factors in the Czech and U.S. automotive markets: Practical implications for marketing. Central European Business Review, 6(1), 26-47. https://doi.org/10.18267/J.CEBR.171

Rivera, M., Croes, R., \& Lee, S. H. (2016). Tourism development and happiness: A residents' perspective. Journal of Destination Marketing \& Management, 5(1), 5-15. https://doi.org/10.1016/j.jdmm.2015.04.002

Rosengren, A. (2018). Gross National Happiness in Business: Theories and Methods for Cultivating GNH in Swedish Work-life. In D. Karma and S. Chohel (Eds.), Proceedings of the Seventh International Conference on Gross National Happiness (pp. 76-100). Retrieved from http://gnhsweden.com/gnh-in-business/

Roshina, I., \& Artyukhova, N. (2016). Social Responsibility, Sustainable Development, Happiness and Well-being of Single Industry Towns' Population. TWELLSO 2016 - III International Scientific Symposium on Lifelong Wellbeing in the World Social, 4350. https://doi.org/10.15405/epsbs.2017.01.6

Ruhanen, L., Weiler, B., Moyle, B. D., \& McLennan, C. lee J. (2015). Trends and patterns in sustainable tourism research: a 25-year bibliometric analysis. Journal of Sustainable Tourism, 23(4), 517-535. https://doi.org/10.1080/09669582.2014.978790

Şahin, Ö. (2018). Happiness Management in Micro, Small and Medium Sized Food and Beverage Enterprises (SMFBEs): Menteşe/Muğla Case. Journal of Business Research - Turk, 10(4), 843-867. https://doi.org/10.20491/isarder.2018.552

Santos, E. (2020). Promoting firms' sustainability in tourism planning through employment. Smart Innovation, Systems and Technologies, 171, 345-355. https://doi.org/10.1007/978-981-15-2024-2_31

Schinzel, U. (2013). Why are people in Luxembourg happy? An exploratory study of happiness and culture measured by the dimension of a language as identifier in the Grand Duchy. Journal of Customer Behaviour, 12(4), 315-340. https://doi.org/10.1362/147539213X13875568505822

Schroeder, K. (2015). Cultural values and sustainable tourism governance in Bhutan. Sustainability, 7(12), 16616-16630. https://doi.org/10.3390/su71215837

Schulte, P. A., Guerin, R. J., Schill, A. L., Bhattacharya, A., Cunningham, T. R., Pandalai, S. P., ... Stephenson, C. M. (2015). Considerations for incorporating "well-being" in public policy for workers and workplaces. American Journal of Public Health. 105(8), 31-44 https://doi.org/10.2105/AJPH.2015.302616

Scott, D. (2011). Why sustainable tourism must address climate change. Journal of Sustainable Tourism, 19(1), 17-34. https://doi.org/10.1080/09669582.2010.539694

Séraphin, H., Platania, M., Spencer, P., Modica, G., Séraphin, H., Platania, M., ... Modica, G. (2018). Events and Tourism Development within a Local Community: The Case of Winchester (UK). Sustainability, 10(10), 3728. https://doi.org/10.3390/su10103728

Sezerel, H., \& Kaymaz, C. (2019). Is Sustainable Tourism a Leverage for Economic Development? A critical review. In B. Christiansen, I. Sysoeva, A. Udovikina, \& A. Ketova (Eds.), Emerging Economic Models for Global Sustainability and Social Development (pp. 46-64). IGI Global. https://doi.org/10.4018/978-1-5225-57876.ch003 
Sgroi, D., Hills, T., O’Donnell, G., Oswald, A., \& Proto, E. (2017). Understanding happiness: A CAGE Policy Report. In Centre for Competitive Advantage in the Global Economy. Retrieved February 01, 2020, from https://warwick.ac.uk/fac/soc/economics/research/centres/cage/publications/polic yreports/policy-report-understandinghappiness/cage_report_understanding_happiness.pdf

Sharpley, R. (2020). Tourism, sustainable development and the theoretical divide: 20 years on. Journal of Sustainable Tourism, 28(11), 1932-1946. https://doi.org/10.1080/09669582.2020.1779732

Sims, R. (2009). Food, place and authenticity: local food and the sustainable tourism experience. Journal of Sustainable Tourism, 17(3), 321-336. https://doi.org/10.1080/09669580802359293

Singh, S., \& Aggarwal, Y. (2018). Happiness at Work Scale: Construction and Psychometric Validation of a Measure Using Mixed Method Approach. Journal of Happiness Studies, 19(5), 1439-1463. https://doi.org/10.1007/s10902-017-9882-x

Sousa, J. M., \& Porto, J. B., (2015). Happiness at Work: Organizational Values and PersonOrganization Fit Impact. Paidéia (Ribeirão Preto), 25(61), 211-220. https://doi.org/10.1590/1982-43272561201509

Southworth, G. (2013). Understanding Human Happiness, Its Measure and a New Leadership Role. Integral Leadership Review, 13(3), 67-86. Retrieved October 1, 2019, from http://integralleadershipreview.com/9072-understanding-humanhappiness-its-measure-and-a-new-leadership-role/

Stiglitz, J. (2019). It's time to retire metrics like GDP. They don't measure everything that matters. The Guardian. Retrieved June14, 2020, from https://www.theguardian.com/commentisfree/2019/nov/24/metrics-gdpeconomic-performance-social-progress

Stiglitz, J. E., Sen, A., \& Fitoussi, J.-P. (2009). Report by the Commission on the Measurement of Economic Performance and Social Progress. Retrieved October 15, 2020, from https://www.researchgate.net/publication/258260767_Report_of_the_Commissio n_on_the_Measurement_of_Economic_Performance_and_Social_Progress_CMEP SP

Sulakhe, P. A., \& Bakre, P. P. (2019). Investigating factors and their impact which affect the happiness index of an entrepreneur. International Journal of Research and Analytical Reviews, 6(1). 353-356

Sweeney, J. R. (2020). The Cost and Benefits of Measuring Sustainability. Faculty and Staff Works. 1. https://kb.gcsu.edu/fac-staff/1

The World Counts. (2019). Negative Environmental Impacts of Tourism - The World Counts. Retrieved September 2020, from https://www.theworldcounts.com/challenges/consumption/transport-andtourism/negative-environmental-impacts-of-tourism/story

Tideman, S. G. (2016). Gross National Happiness: lessons for sustainability leadership. South Asian Journal of Global Business Research, 5(2), 190-213. https://doi.org/10.1108/SAJGBR-12-2014-0096

Tien, N. H., Anh, D. B. H., \& Ngoc, N. M. (2020). Corporate financial performance due to sustainable development in Vietnam. Corporate Social Responsibility and Environmental Management, 27(2), 694-705. https://doi.org/10.1002/csr.1836

UN, G. A. (n.d.). The UN and happiness. Retrieved May 13, 2018, from https://www.unric.org/en/happiness/27709-the-un-and-happiness 
UN General Assembly. (2012). Resolution 66/281 [International Day of Happiness]. Retrieved August 20, 2019, from https://happinessday.org/resolutions/

Union for the Mediterranean (n.d). Blue Economy in The Mediterranean. Retrieved October 16, 2020, from https://ufmsecretariat.org/wpcontent/uploads/2017/12/UfMS_Blue-Economy_Report.pdf

United Nations (2012). Happiness: towards a holistic approach to development Draft note. Retrieved October 16, 2020 from https://digitallibrary.un.org/record/715187

UNWTO (2017). Measuring Sustainable Tourism: A Call for Action - Report of the 6th International Conference on Tourism Statistics, Manila, Philippines, 21 - 23 June 2017. In Measuring Sustainable Tourism: A Call for Action - Report of the 6th International Conference on Tourism Statistics, Manila, Philippines, 21 - 23 June 2017. https://doi.org/10.18111/9789284418954

UNWTO (2018). Statistical Framework for Measuring the Sustainability of Tourism. Retrieved October 16, 2020, from https://www.unwto.org/standards/statistical-frameworkfor-measuring-the-sustainability-of-tourism

Ura, K., Alkire, S., \& Zangmo, T. (2012). GNH and GNH Index. The Centre for Bhutan Studies, (May), 1-60. Retrieved February 14, 2020, from http://www.ophi.org.uk/wpcontent/uploads/Ura-et-al-Bhutan-Happiness-Chapter.pdf

Verma, R. (2017). Gross National Happiness: meaning, measure and degrowth in a living development alternative. Special Section of the Journal of Political Ecology Verma Gross National Happiness Journal of Political Ecology, 24(24), 425-666. Retrieved October 16, 2020, from http://jpe.library.arizona.edu/volume_24/Verma.pdf

Vikash, V. (2019). Human Development Index and Gross National Happiness Indices: A Conceptual Study. Advances in Management 12. Retrieved October 16, 2020 from https://worldresearchersassociations.com/mngmntspecialissue/10.pdf

Weaver, D. B. (2012). Opinion Piece Organic, incremental and induced paths to sustainable mass tourism convergence. Tourism Management, 33, 1030-1037. https://doi.org/10.1016/j.tourman.2011.08.011

Wu, K.-J., Zhu, Y., Chen, Q., \& Tseng, M.-L. (2019). Building Sustainable Tourism Hierarchical Framework: Coordinated Triple Bottom Line Approach in Linguistic Preferences. Journal of Cleaner Production. 229, 157-168. https://doi.org/10.1016/j.jclepro.2019.04.212

Zangmo, T., Wangdi, K., \& Phuntsho, J. (2017). Proposed GNH of Business Bhutan: Centre for Bhutan Studies \& GNH. Retrieved February 20, 2020 from http://www.bhutanstudies.org.bt/wp-content/uploads/2017/11/GNH-of-Business.pdf

Zhechev, V. S., \& Zhecheva, D. P. (2019). Ethical Branding: A Corporate Commitment or Compliance with Contemporary Trends. Annals of Marketing-Mba, Department of Marketing, Marketing MBA (RSconsult), 4(December), 72-90. Retrieved from https://www.marketing-mba.ru/article/v4_19/Zhechev.pdf

Zhong, R. (2015, December 17). In Bhutan, Gross National Happiness Trumps Gross National Product. Wall Street Journal (Online), 1.

Zolfani, S. H., Sedaghat, M., Maknoon, R., \& Zavadskas, E. K. (2015). Sustainable tourism: A comprehensive literature review on frameworks and applications. Economic $\begin{array}{lll}\text { Research-Ekonomska Istrazivanja, } & \text { 28(1), }\end{array}$ https://doi.org/10.1080/1331677X.2014.995895 